\title{
Monsoons: global energetics and local physics as drivers of past, present and future monsoons
}

Article

Accepted Version

Biasutti, M., Voigt, A., Boos, W. R., Braconnot, P., Hargreaves, J. C., Harrison, S. P., Kang, S. M., Mapes, B. E., Scheff, J., Schumacher, C., Sobel, A. H. and Xie, S.-P. (2018) Monsoons: global energetics and local physics as drivers of past, present and future monsoons. Nature Geoscience, 11 (6). pp. 392-400. ISSN 1752-0894 doi: https://doi.org/10.1038/s41561-0180137-1 Available at https://centaur.reading.ac.uk/76799/

It is advisable to refer to the publisher's version if you intend to cite from the work. See Guidance on citing.

To link to this article DOI: http://dx.doi.org/10.1038/s41561-018-0137-1

Publisher: Nature Publishing Group

All outputs in CentAUR are protected by Intellectual Property Rights law, including copyright law. Copyright and IPR is retained by the creators or other copyright holders. Terms and conditions for use of this material are defined in the End User Agreement. 


\section{CentAUR}

Central Archive at the University of Reading

Reading's research outputs online 


\section{Monsoons: global energetics and local physics}

2 Michela Biasutti ${ }^{1}$, Aiko Voigt ${ }^{2,1}$, William R. Boos ${ }^{3}$, Pascale Braconnot ${ }^{4}$, Julia C. Hargreaves ${ }^{5}$,

${ }_{3}$ Sandy P. Harrison ${ }^{6}$, Sarah M. Kang ${ }^{7}$, Brian E. Mapes ${ }^{8}$, Jacob Scheff $^{9}$, Courtney Schumacher $^{10}$,

4 Adam H. Sobel ${ }^{1,11}$, \& Shang-Ping Xie ${ }^{12}$

$5{ }^{1}$ Lamont-Doherty Earth Observatory of Columbia University, Palisades, NY 10964, USA

$6 \quad{ }^{2}$ Institute of Meteorology and Climate Research - Department Troposphere Research, Karlsruhe

7 Institute of Technology, Karlsruhe, Germany

$8{ }^{3}$ Department of Earth and Planetary Science, University of California, Berkeley CA 94720-4767,

9 USA

${ }^{4}$ Laboratoire des Sciences du Climat et de l'Environnement, Unite mixte CEA-CNRS-UVSQ, 91191 Gif-sur-Yvette Cedex, France

${ }^{5}$ BlueSkiesResearch.org.uk, The Old Chapel, Albert Hill, Settle BD24 9HE, UK

${ }^{6}$ School of Archaeology, Geography and Environmental Science, University of Reading, Whiteknights, Reading RG6 6AH, UK

${ }^{7}$ School of Urban and Environmental Engineering, Ulsan National Institute of Science and Technology, Ulsan, South Korea

${ }^{8}$ University of Miami, Miami, FL 33149, USA

${ }^{9}$ Department of Geography and Earth Sciences, University of North Carolina, Charlotte, NC 28223, USA

${ }^{10}$ Department of Atmospheric Sciences, Texas A\&M University, College Station, TX 77843-3150, USA

${ }^{11}$ Department of Earth and Environmental Sciences and Department of Applied Physics and Applied Mathematics, Columbia University, New York, NY 10027

${ }^{12}$ Scripps Institution of Oceanography, University of California San Diego, 9500 Gilman Drive, MC 206, La Jolla, CA 92093, USA 
Global constraints on momentum and energy govern the structure of the zonal mean tropical circulation and rainfall. The continental-scale monsoon systems are also facets of a momentum- and energy-constrained global circulation, but their modern and paleo variability deviates substantially from that of the longitudinal mean through mechanisms neither fully understood nor well simulated. A framework grounded in global constraints yet encompassing the complexities of monsoon dynamics is needed to identify the causes of mismatch between theory, models, and observations and, ultimately, improve regional climate projection. In a first step towards this goal, disparate regional processes must be distilled into gross measures of energy flow in and out of continents and from the surface to the tropopause, so that monsoon dynamics may be coherently diagnosed across modern and paleo observations and across idealized and comprehensive simulations. Accounting for zonal asymmetries in the circulation, land/ocean differences in surface fluxes, and the character of convective systems, such a monsoon framework would integrate our understanding at all relevant scales: from the fine details of how moisture and energy are lifted in the updrafts of thunderclouds, up to the global circulations.

Most tropical precipitation, whether steady rain or intense showers, falls from cloud clusters where individual, small-scale updrafts are organized over a few hundred kilometers in discrete weather systems. These, in turn, are orchestrated by planetary-scale circulation features: the monsoons and the Inter-Tropical Convergence Zone (ITCZ, Figure 1a and b). The clustering of individual clouds is the visible signature of an otherwise invisible global stirring. The notion that a link exists between smaller and larger scales underpins our understanding of tropical rain belt dynamics and is the basis of their representation in global climate models. Our understanding, however, remains incomplete, as evidenced by our inability to achieve reliable predictions of how the ITCZ and monsoons respond to external forcings.

Without the benefit of outdoor controlled experiments, or the possibility of validating pre- 
dictions of long-term future changes, the reliability of our prediction tools must be tested against past records. Confidence in projected climate responses increases when dynamic theories built on contemporary observations also explain past conditions and when simulations skillfully reproduce the paleo record.

Good tests of our theories and models are the Holocene waxing and waning of monsoons in response to orbitally-driven changes in incoming solar radiation ${ }^{1,2}$ (Figure 2). During the early to mid Holocene (11,000-5,000 years before present), the Northern Hemisphere received more insolation during its summer than today, while the Southern Hemisphere received less during its summer. In the modern climate, monsoons export energy from regions where the sun delivers most-so we would expect mid-Holocene monsoons to be stronger in the Northern Hemisphere and weaker in the Southern Hemisphere, compared to today. Paleoenvironmental data from that period indeed indicates increased rainfall in North and Central America ${ }^{3,4}$, a stronger Indian monsoon and increased inland penetration of the monsoon into China ${ }^{5,6}$, and a spectacular rainfall expansion in northern Africa ${ }^{7,8}$ : abundant lake, pollen and archaeological evidence documents wetting and vegetation increase over much of the Sahara.

While qualitatively consistent with our expectations, the major expansion of the Northern Hemisphere monsoons is widely underestimated in climate model simulations ${ }^{1,2}$, in particular over the Sahara ${ }^{9}$ (Figure 2b). This bias can be reduced by modeling earth-system feedbacks ${ }^{10}$ or by imposing the observed changes in vegetation, surface water storage, wetlands, soils, and mineral dust as boundary conditions ${ }^{11-13}$. Yet, simulations that organically produce both the rainfall distribution and the vegetation types that are consistent with the records still elude $\mathrm{us}^{2}$. Moist atmospheric dynamics and its coupling with other aspects of the Earth system, including vegetation cover and soil properties, remain prime suspects for the failures. Moreover, the sign of observed Southern-Hemisphere changes is not fully consistent with the predictions of reduced rainfall from 
both arguments based on the hemispheric summertime insolation forcing and complex model simulations. Although many more quantitative estimates of rainfall anomalies from the Southern Hemisphere are needed to paint a full picture, many palaeoenvironmental records from Southern Africa imply increased precipitation ${ }^{14}$ and palaeoenvironmental records from South America and Australia seem to show (their interpretation being somewhat controversial) mixed wetting and drying signals ${ }^{15,16}$. Thus, neither complex models nor theoretical intuition are sufficient to explain past monsoon records.

In a traditional dry paradigm, monsoon circulations are akin to continental-scale land-sea breezes driven by surface temperature contrast, their strength increasing with the contrast. But this is too simplistic. Monsoon lands are hottest before the start of the monsoon, but the circulation is strongest in late summer (when increased rain and cloudiness have cooled the land and reduced the contrast). In future climate projections, land-sea temperature contrasts universally strengthen, but monsoon circulations generally weaken ${ }^{17}$ as does, in some instances, regional early-season rainfall $^{18,19}$.

A better paradigm views monsoons not as giant heat lows for which rainfall is a side effect, or as circulations "driven by" the latent heating of rainfall, but as moist energetically-direct circulations tightly coupled to precipitating convection; a facet of the general overturning of the tropical atmosphere inextricably linked to the Hadley circulation and the zonal mean ITCZ ${ }^{20}$.

At seasonal time scales, convection acts to release any column instability and to bring the free-tropospheric temperature in line with the moist static energy (MSE) of the boundary layer below $\mathrm{it}^{21}$. Horizontal atmospheric motions homogenize the free-tropospheric tropical temperatures to one vertical profile which reflects the conditions of the major convective centers. In this view, peak rainfall should coincide with peak low-level MSE; cooler and dryer surfaces can support only shallower or suppressed convection. Land and ocean observations confirm this theoretical 
prediction $^{22}$. Meanwhile, the upper-level divergence over these convective regions (maxima of low-level MSE) implies that the circulations associated with peak rainfall export total energy away from the centers of deep convection. In other words, monsoons and the ITCZ are components of a planetary energetically-direct circulation that links land and ocean rainfall (similar to a "global monsoon" ${ }^{23}$ ) and shows coherent variability from seasonal ${ }^{24,25}$ to geological time scales ${ }^{20,26,27}$. Such an encompassing view is an important theoretical advance. Its formulation for the zonal mean tropical circulation-known in the literature as the energy-budget framework-underpins our understanding of why the ITCZ moves meridionally in response to forcings that originate well outside the tropics ${ }^{20,28,29}$ (Section 1).

Further progress in understanding and simulating regional rainfall anomalies requires us to extend the energy-budget framework developed for the Hadley circulation to describe how the full tropical circulation redistributes energy vertically and horizontally, from its poleward boundaries and across the tropics. The extension of the energy-budget framework from a purely zonal formulation to one that includes zonal asymmetries would parallel the progress that has been made in understanding how the momentum budget constrains tropical circulations. The momentumbudget framework has led us from a starting view of the Hadley circulation ${ }^{30}$ and-to a degreethe monsoons ${ }^{31}$ as axisymmetric angular-momentum-conserving circulations, to the recognition that momentum transport by eddies is crucial to maintaining the zonal mean circulation in most cases $^{32,33}$, to a deepening understanding of the role of the vorticity transport by stationary eddies in both localizing the monsoon circulation and regulating its intensity ${ }^{34,35}$. An analogous energy-budget framework would invoke zonal asymmetries in surface properties, which introduce horizontal gradients in the distribution of energy, amplify the importance of both stationary and transient eddy transports, and can generate shallow circulations which can be energetically indirect (Section 2). These asymmetries are expressed in the observable differences in convective weather characteristics between land and ocean (Figure 1c and d), which aggregate into different 
ascent profiles and vertical energy transport (Section 3).

The eventual goal is to combine the momentum-based and energy-based theories of tropical circulations and rainfall into a self-contained model for the tropical climate, one that describes how the interplay between energy and momentum fluxes in a moist atmosphere-where a profusion of weather phenomena, cloud types, and scales of motion is organized in mean and eddy effectsdrives the seasonal evolution of oceanic and continental rainfall and controls monsoon diversity, variability, and response to external forcing. Understanding how the clouds within such circulations modify the energy input into the atmosphere through changes in both radiative fluxes and turbulent surface fluxes would be the next challenge ${ }^{36-38}$. In the rest of this paper, we propose a first step towards our goal: an energy-budget framework suitable for monsoons.

\section{The explanatory power of energetic constraints.}

Energetic constraints provide a parsimonious explanation of how the zonal-mean tropical rainfall shifts its position in response to internal variability and external forcings ${ }^{20,28,29}$. The ascending branches of the Hadley cells are in the deep tropics, where the solar radiation absorbed by the earth most greatly exceeds the terrestrial radiation emitted to space. Energy is transferred from the surface to the atmosphere by fluxes of radiation, sensible heat and moisture (latent heat) and a planetary circulation moves this excess energy towards high latitudes (Fig. 3a). Moist surface air converges and rises in the ITCZ, thus cooling adiabatically, condensing moisture, and forming precipitating clouds. As a result, maximum rainfall is broadly co-located with the boundary between the Hadley cells (Fig. 3c).

These ideas can be formalized by focusing on the atmospheric energy budget in the annual and zonal means $\mathrm{s}^{20,28}$. Averaging in time and longitude disposes of tendency terms and zonal fluxes, so that, under the assumption that eddy terms are unimportant, net energy input into the atmosphere 
is balanced by the divergence of the vertically integrated energy flux by the Hadley circulation $\mathcal{F}$ and the ITCZ coincides with the "energy-flux equator," i.e., the latitude at which the energy flux $\mathcal{F}=0$ and changes direction.

The Coriolis force is weak in the tropics and atmospheric waves are effective in smoothing out pressure gradients. Because the tropical troposphere cannot maintain strong temperature gradients, an extra-tropical eddy heat flux that reaches the tropics will be carried into the tropics and through — to the mid latitudes of the other hemisphere. This argument appears to apply more broadly: any asymmetry in the energy flux across the northern and southern edges of the tropics is felt throughout the tropical band ${ }^{39}$, making the position of the energy-flux equator sensitive to extra-tropical forcings ${ }^{20}$. The same argument explains how the inter-hemispheric asymmetry in seasonal insolation drives the north-south annual migration of the ITCZ ${ }^{24}$. However, because the cross-equatorial Hadley cell is always the strongest throughout the annual cycle, and because maximum ascent and rainfall are concentrated within the cross-equatorial cell and equatorward of the energy-flux equator, seasonal rainfall shifts are less pronounced than those of the energy-flux equator $^{24}$ (Fig. 3a). In comprehensive models, changes in the annual-mean position of the ITCZ, their inter-model spread, and the seasonal migration of the rain belt have been shown to follow the same quantitative relationship with energy transports, albeit with some scatter and uncertainty (a 1PW change in the cross-equatorial energy flux leads to about a $3^{\circ}$ shift in the position of the ITCZ, Fig 3b). This correspondence has been used to suggest that the same dynamics control both the meridional shifts characteristic of the annual cycle and the variability of mean rainfall at paleo time scales ${ }^{20,24,40}$.

This theory for the ITCZ position sees the tropical rain belt as the expression of the conservation law that governs energy in the climate system; it links the occurrence of convection not just to the local environment, but to the planetary adjustments that bring the global atmosphere towards 
equilibrium; and it subsumes arguments that link the ITCZ position to gradients in tropical SST. It has been used to explain the location of the modern ITCZ north of the equator as a consequence of energy transport by the thermohaline ocean circulation ${ }^{41}$, the southward shift of tropical rainfall during the last glacial maximum and Dansgaard-Oeschger events as a consequence of northern high-latitude cooling ${ }^{29,40}$, the effect of Eurasian afforestation on monsoons in the mid Holocene ${ }^{42}$, the Sahel drought in the 1970's and 1980's as part of a global-scale southward ITCZ shift due to sulfate aerosols $\mathrm{s}^{43}$, and the role of Southern Ocean heat uptake in setting up the hemispheric asymmetry in future tropical rainfall changes ${ }^{44}$.

However, the existing framework is limited in important ways. First, it is incomplete as a predictive theory because internal radiative feedbacks from clouds and water vapour can overwhelm the external forcings in setting energy gradients, are not easily predicted from gross energetic constraints, and vary substantially between models ${ }^{36,37,45}$. Even when the radiative effect of clouds is carefully controlled in models ${ }^{46,47}$, changes in oceanic heat transport can oppose the inter-hemispheric difference in energy input in the atmosphere and complicate the response of the ITCZ ${ }^{48}$ to external forcings. Indeed, the tight coupling between atmospheric and oceanic heat transport ${ }^{20,49-51}$ suggests an expansion of atmospheric-only arguments. Second, changes in tropical rainfall are often better described as intensifications ${ }^{52}$ or contractions ${ }^{19,53-56}$ of the climatological net rainfall pattern, rather than shifts, and some regional anomalies are strongly driven by localized gradients in surface conditions ${ }^{57-59}$, including between ocean and land ${ }^{60,61}$. Third, the assumption that rainfall is the product of deep convection in which ascent extends throughout the troposphere and maximizes at mid levels is crucial to the portrayal of the Hadley cell as energetically direct. Quantitatively, this requires that the same large-scale circulation that converges moisture into the ITCZ also diverges enough static energy from the ITCZ at upper levels that the vertically-integrated result is a net export of MSE - a result that depends heavily on where exactly in the column air is converging and diverging. Yet, rainfall is also produced in circulations with shallow components 
and bottom-heavy ascent profiles (see also Fig 4), and direct calculation of the energy flux out of such regions indicate a net import of energy ${ }^{62,63}$. Fourth, the assumption in the ITCZ energy-budget framework that eddies are not important is debatable. Even well within tropical latitudes, transient eddies transport latent heat poleward ${ }^{64}$ and thus might be as important as the zonal circulation in transporting energy, especially where the latter is weak. While the bulk effect of transient eddies could be subsumed into the framework developed for the ITCZ in an aquaplanet ${ }^{28,65}$, the presence of land introduces stationary eddies ${ }^{34,66}$ and localizes transient eddies ${ }^{31}$ in ways that preclude the straightforward application of the zonal mean framework to limited longitude bands (Fig 2c). This is particularly true in a moist atmosphere, where feedbacks between surface fluxes, clouds, and latent and radiative heating can amplify and extend the asymmetries in the forcing ${ }^{45}$. These limitations hamper our ability to use the existing energy-budget framework for the ITCZ to accurately predict the response of regional rainfall to past or future forcings. Yet the fundamental insight that regional changes are expressions of global conservation laws should not be abandoned.

\section{The need for an energy-budget framework for monsoon systems.}

Zonal asymmetries and contrasts between land and ocean are fundamental to the energy and the momentum budget of monsoon circulations ${ }^{13,34,67,68}$. To close, the energy budget must include the effect of zonal transports and of the complex vertical structure of the meridional circulation, both of which are the result of inhomogeneities in surface properties. Inhomogeneities do occur over oceans (such as between warm pools and the equatorial cold tongues), but gradients in surface properties are especially strong at coastlines and over continents due to orography, variability in the characteristics of soils and vegetation, and-in a positive feedback-to the response of the land system to differences in precipitation. The conceptual model of the Hadley cell as a simple deep overturning meridional circulation (Fig. 3c) can broadly capture the main features of the ITCZ, but is insufficient to describe the more complex monsoon circulations. In many regional 
monsoons ${ }^{22,69}$, gradients in surface temperature and sensible heat fluxes (e.g., between the hot subtropical desert and the cooler oceans and equatorial rainforests) force a shallow circulation with dry ascent poleward of the monsoon rainfall. This circulation includes the low-level monsoon flow that fuels moisture to the rainfall band and the dry return flow above that can cap deep convection, affecting the frequency of rainfall and the occurrence of severe convection (Figure 1c,d and 3c). Re-evaporation of rainfall in a dryer lower troposphere (Fig. 3c, cloud types) can also affect the vertical distribution of latent heating and, concurrently, ascent (see also the next section). The presence of land, thus, changes the vertical transports in the meridional divergent circulation. The strong horizontal gradients in temperature and moisture associated with surface type also induce strong non-divergent, rotational flows that transport energy and moisture horizontally (Fig. 3c, broad arrows). Past seminal work ${ }^{67}$ has shown that ventilation, the transport of low-MSE oceanic air by the rotational flow, is key to setting the poleward extent of the monsoon rainfall. Recent studies with more comprehensive models have confirmed the important role of the rotational flow in balancing the energy budget of monsoon regions ${ }^{70}$ and in driving the onset of off-equatorial rainfall ${ }^{34}$. The annual changes in surface properties that take place during the progression of the rainy season are also reflected in changing flows of energy in the atmosphere. The most obvious change is soil water content, which affects evaporative fluxes and albedo and, because of its high spatial variability, can introduce sharp gradients in surface properties at small spatial scales ${ }^{71}$.

There is a vast literature that focuses on the individual regional monsoons and emphasizes the zonally asymmetric regional flow and its interaction with mountains and regional oceans. There is value in formulating such regional analysis within a MSE framework. For example, the extent and intensity of the South Asian monsoon depends on the presence of the Himalayan mountains because the latter shield the MSE maximum over India from low-MSE extratropical air $^{72}$. In another example, the African monsoon appears to be particularly susceptible to moisture anomalies entering from the North Atlantic ${ }^{73-76}$ and the Mediterranean ${ }^{77}$ (even though the main moisture source 
for the monsoonal rains is in the tropical ocean) because they regulate the depth of convection, ${ }^{78}$ which is in turn linked to energetic requirements of the large-scale flow ${ }^{70}$. How the profile of convective ascent evolves across the monsoon season modulates such sensitivity, by making changes in either the boundary layer MSE (such as the horizontal advection or recycling of moisture) or the free-tropospheric dynamics (such as changes in upper-level vertical stability) more or less relevant (a similar dependence of rainfall sensitivity on low-level and upper-level processes is also seen across models $\left.{ }^{70,73}\right)$.

The broad-brush framework built around the MSE budget has been successful in explaining why and how processes as disparate as aerosol microphysics and the oceanic thermohaline circulation can affect the zonal mean tropical rainfall. Here, we advocate extending the energybudget framework from its current form, appropriate to the ITCZ/Hadley cell, to one appropriate for monsoons: one that quantifies how the presence of zonally-confined land masses modifies both the input and the flow of energy in the atmosphere and thus changes the leading terms of the vertically-integrated atmospheric energy budget. In this section we have emphasized (i) how land/ocean differences in surface properties change the input of moist and dry energy to the atmosphere, (ii) how the continental-scale stationary circulations that develop in response advect MSE gradients horizontally through the geostrophic flow, and vertically through shallow circulations, and (iii) how changes in the dominant balance shape both the diversity of regional monsoons and monsoon evolution through the development and decay of the rainy season. In the next section we focus on the role of vertical motion at the scale of clouds, and how it shapes the vertical fluxes of moist energy and its input in the atmosphere. 


\section{The diversity of convection in tropical precipitation systems: interaction with the large- scale climate.}

Recent observations have highlighted the rich diversity of convective systems (Figs. 1 and 4), and have allowed fundamental insights into the processes that govern them. Convective precipitation appears controlled by both low-level and deep-column moisture, which set the buoyancy of entraining ascending parcels. Thus, while early theories predict the position of the rainfall maximum from just the boundary-layer MSE (Sec. 1), full tropospheric water vapour is key to fully account for the spatial and temporal variability of rainfall intensity. In turn, processes such as detrainment from precipitating clouds and re-evaporation of rain make the tropospheric water vapour depend on the occurrence of rainfall. This two-way coupling underpins the correspondence between rainfall amounts and total humidity found over land and ocean (see also Fig 1a) and is encapsulated in an exponential relationship of daily precipitation intensity on the integrated humidity ${ }^{79}$ (with some variations across convective system ${ }^{80}$ and their drivers ${ }^{81}$ ). However, rainfall characteristics, such as intensity, organization, and duration, and the vertical and temporal distribution of clouds depend on factors other than column humidity, including wind shear, the larger-scale flow, and the properties of the surface boundary ${ }^{71,82,83}$. Continental updrafts are often deeper and more intense than oceanic updrafts (Fig. 4a,b), as evidenced by the preferential occurrence of lightning over land (Fig. 1c), but land convection varies greatly through the day (cf. Figs. $4 \mathrm{c}$ and d) and the season in depth, organization, and lifetime - affected by surface inhomogeneity and by stronger triggering and inhibition processes.

The growing appreciation of the diversity of convective cloud systems has yet to mature into enough understanding of the interplay between clouds and large-scale dynamics to create muchneeded convective parameterizations able to describe such diversity. Parameterizations are still overly reliant on so-called quasi-equilibrium formulations: the gross effects of convection are taken 
to be nearly instantaneous and deterministic functions of large-scale forcings, thermodynamics drivers are overemphasized over dynamics, and convective organization is typically ignored ${ }^{84,85}$. The approximations lead to a preference for tall, disorganized convection and the lack of both shallower, developing convection ${ }^{86}$ and more persistent cloud systems and is likely the source of climate models' systematic errors in rainfall timing (for example, the too-early peak in the diurnal cycle of land rainfall). It affects the climate at longer time scale as well: model biases in seasonal rainfall are typically established within few days after initialization from observations, and only later amplified in the coupled system, pointing to the dominance of fast atmospheric processes ${ }^{87}$ in setting the bias. Such long-ranging effects are not surprising: the aggregate effect of convection is reflected in the profiles of horizontal convergence and divergence and in cloud and moisture radiative effects and will thus affect both the net vertically-integrated energy flux and the total energy input into the atmosphere. The extent and vertical distribution of clouds modify the net energy in the atmosphere via changes in radiative fluxes and, by modifying the structure of the boundary layer, turbulent fluxes. The vertical profile of ascent modulates the energy transport by the circulation, to the point that a predominance of bottom-heavy or top-heavy convection can determine whether the circulation imports or exports MSE to or from a convective region ${ }^{62,63}$. Thus, shortcomings in the mix of deep convective and stratiform rain production, of warm and cold cloud microphysics, and of mixing and re-evaporation, can translate into global scale biases ${ }^{88}$ and introduce another source of uncertainty in future projections ${ }^{70}$.

High-resolution cloud-resolving dynamical models can portray the full evolution and organization of cloud systems ${ }^{88,89}$ and — when coupled to parameterized large-scale fields ${ }^{90}$ that describe a broad suite of boundary conditions and environments - are being used to investigate how the environment shapes the rich diversity of cloud characteristics and how cloud processes feed back on the environment. These experiments have shown that the specific way in which land convection evolves during the day (such as through morning fog or land-sea breezes) is a key determinant of 
the large-scale mean and the seasonal evolution of rainfall and other environmental variables ${ }^{91,92}$. More research on tropical land convection is needed to elucidate whether this cross-scale link is achieved because land processes and clouds modify the energy input into the atmosphere, or because the daily evolution of convection changes the profile of ascent and this effect is rectified into changes in the vertical energy flux.

\section{Synthesis}

Common biases in the simulation of the diurnal and seasonal cycle of rainfall highlight structural deficiencies across global climate models. Moreover, common biases in the simulation of rainfall in past climate states indicate that common structural deficiencies also affect the modeled responses to changes in forcing. This diminishes the value of consensus in projections of climate response to anthropogenic forcings as an indication of reality. Convective parameterizations, which produce most tropical rainfall within current climate models, have inherent limitations that are a likely cause of bias, but whether cloud-resolving global models will be able to adequately capture observed rainfall variations in modern or past climate states remains to be seen. Oceanic processes that amplify atmospheric biases in the seasonal cycle ${ }^{93}$ are likely to play a role in setting long-term trends ${ }^{94}$ and paleo simulations highlight the additional importance of earth-system feedbacks, such as between precipitating atmospheric dynamics, vegetation cover, and soil composition. Having a small set of metrics by which to characterize simulations of a climate phenomenon would make the task of model development less daunting; a modern energy-budget framework, one modeled on past efforts ${ }^{20,21,32,95,96}$ but aware of the advances and challenges outlined in this review, can supply such metrics for tropical rainfall.

Developing the framework we are advocating will require the combination of observational, modeling and theoretical approaches. Both modern and paleo observations must be the ultimate 
tests of our theories. Fine-resolution, high-frequency observations of rainfall and of the vertical atmospheric structure, together with cloud-resolving simulations, have the potential to shed muchneeded light on how convection becomes organized and how monsoon rainfall interacts with its environment from sub-daily to monthly timescales ${ }^{84}$. To be truly useful for benchmarking metrics and developing parameterizations, current efforts must be expanded to encompass a broader cross section of tropical environments and climate regimes-including a variety of chronically undersampled land regions. Collection of new paleo evidence and quantitative reconstructions of precipitation from the Southern Hemisphere will refine our picture of paleo monsoons in the mid Holocene and provide a well defined target for testing model simulations and their interpretation within this common framework. The opposite is also true: forward proxy models and climate models are needed to guide the interpretation of data, morph sparse environmental observations into a coherent portrait of past climates, and help prioritize new data acquisition. Multi-model simulations ${ }^{97}$, simulations with a broad set of forcings ${ }^{48}$, and simulations with models of different vintage are needed together to provide a robust test for a new monsoon framework.

Drawing our lessons from the development of budget-based theories of the ITCZ, we propose that a systematic understanding of the monsoons will require a comprehensive hierarchy of model simulations and a common set of energy and momentum diagnostics to compare results across the model hierarchy and with observations. A key element of such a hierarchy are idealized model setups in which energy is conserved through fluxes at the atmospheric boundaries and that are designed to highlight the effect of different land characteristics - themselves isolated through ad-hoc idealizations - on the response of the tropical rain belt to a range of external forcings ${ }^{98-100}$. Accurate diagnostics of how energy flows into and within the tropical atmosphere, and via different elements of the atmospheric circulation (from the zonal mean, to stationary eddies, to synoptic eddies, to much faster variability at the scale of convection) are often difficult to calculate from available model output ${ }^{54}$. Yet they must underpin any metrics used to elucidate which small- and 
large-scale processes are essential to the monsoon systems (and by which interactions); to test the coherence of our dynamical theories; and to benchmark model development. A theoretical model that can deduce the behavior of tropical rainfall from simple indicators based on conservation laws of the physical system with minimal empirical or ad-hoc assumptions would cap the hierarchy and provide the grounds for interpreting both idealized and realistic simulations and for understanding the observed behavior of the earth system. To derive a unified theory of the ITCZ and the regional monsoons from basic conservation laws is a formidable challenge, but we must meet it to confidently link past to present to future. 
Correspondence Correspondence and requests for materials should be addressed to M.B. (email: biasutti@1deo.columbia.edu).

Acknowledgements We gratefully acknowledge the contributors to the workshop "Monsoons \& ITCZ: the annual cycle in the Holocene and the future", held at Columbia University in September 2015: the original idea for this perspective was born of the insights and excitement engendered by their results and from the lively community discussion of ideas and approaches. The workshop was conceived under the aegis of the World Climate Research Program (WCRP) Grand Challenge on Cloud Circulation and Climate Sensitivity, and was made possible by the generous support of the Columbia Climate Center and the Columbia Initiative on Extreme Weather and Climate. NSF award AGS-1536461 supported the participation of early career scientists.

We thank Aaron Funk for the analysis displayed in figure 4, and Beth Tully for her graphical expertise in producing Figures 1 and 3.

We gratefully acknowledge the National Aeronautic and Space Administration (NASA) for TRMM3B42 and GPM rainfall data, TRMM2A23 and TRMM2A25 reflectivities, and MERRA reanalysis; the National Oceanic and Atmospheric Administration (NOAA) for the CMAP rainfall data; the European Centre for Medium Range Weather Forecasting (ECMWF) for the ERA Interim reanalysis; and the WCRP's Working Group on Coupled Modelling and all participating modeling centers for CMIP5 and PMIP3 data. M.B., A.V. and J. Scheff are supported by NSF award AGS-1565522. M.B. is supported by DOE award DESC0014423. A.V. is supported by the German Ministry of Education and Research (BMBF) and FONA: Research for Sustainable Development (www.fona.de) under grant agreement 01LK1509A.

Competing Interests The authors declare that they have no competing financial interests.

Authors' Contributions MB lead the writing process and produced Figure 1 (from an idea by BEM), Figure 2 (from data provided by SPH and PB), and Figure 3 (in collaboration with WRB and AV). CS produced Figure 4. All authors collaboratively drafted the outline of the paper and greatly contributed to the writing process. 
27 July 2015

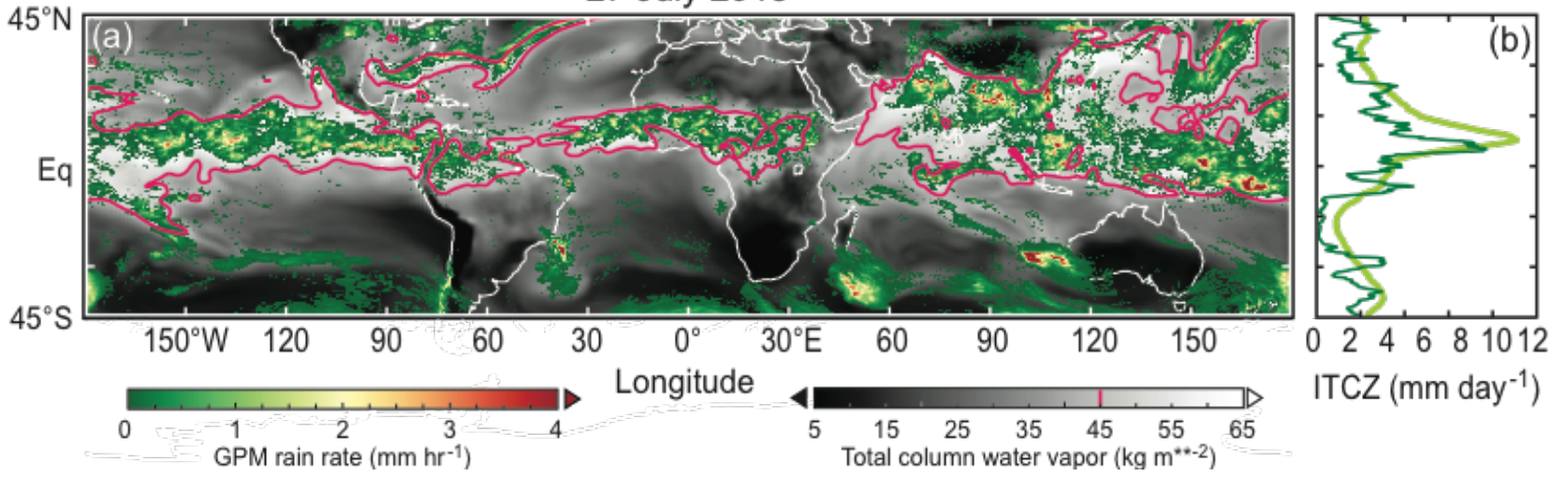

July 1998-2007

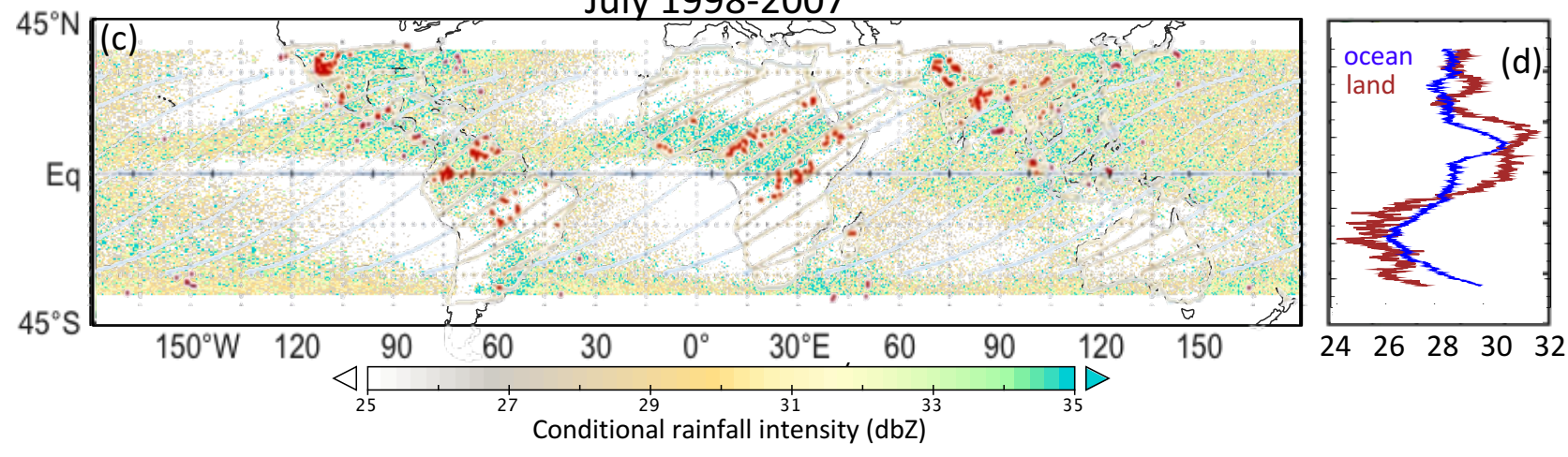

Figure 1: (a) Rainfall (color) on July 27th, 2015 and the high atmospheric moisture enveloping it (indicated by the $45 \mathrm{~mm}$ contour of column-integrated water vapour, the full field is in gray); (b) zonal-mean rainfall for the same day (dark green) and climatological values for the same period (light green). (c) July climatological mean intensity of instantaneous near-surface rainfall (from TRMM precipitation radar, units of reflectivity) and occurrence of lightning (red dots) on July 27th, 2014 (ascending passes of the Lightning Imaging Sensor on TRMM). (d) zonal mean rainfall intensity for land and ocean regions. See on-line method section for further details. 

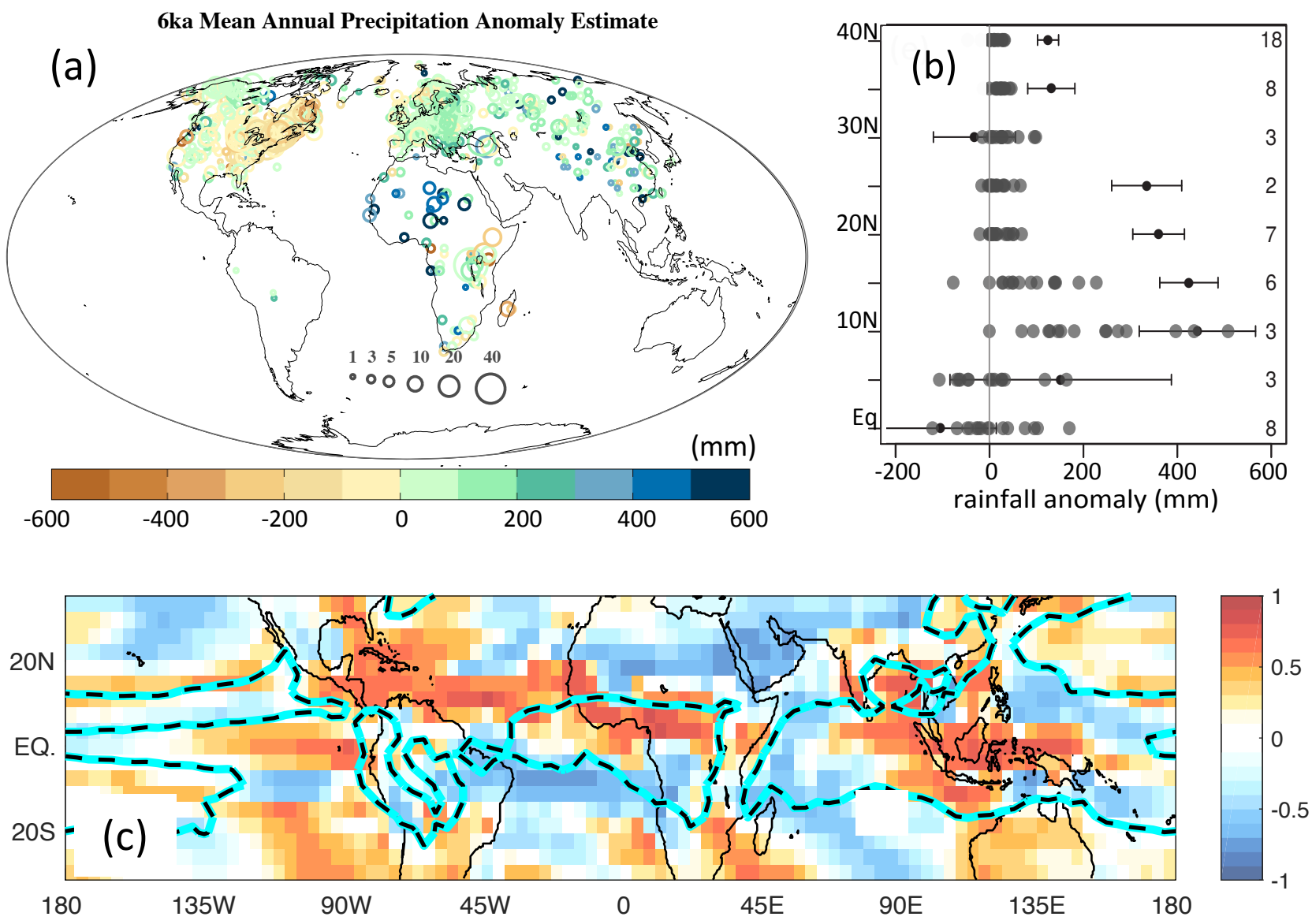

Figure 2: (a) Mid-Holocene mean annual precipitation (MAP) anomalies (color circles, sized by the number of used reconstructions). (b) CMIP5/PMIP3 simulated (gray circles) and reconstructed (black circles with error bar) mid-Holocene MAP changes and grid cells contributing to the reconstruction and model means (numbers at right) for northern Africa latitude bands. (c) Correlation of decadal rainfall variations with the first principal component of the zonal-mean precipitation in transient Holocene simulations. See methods for data references and details. 

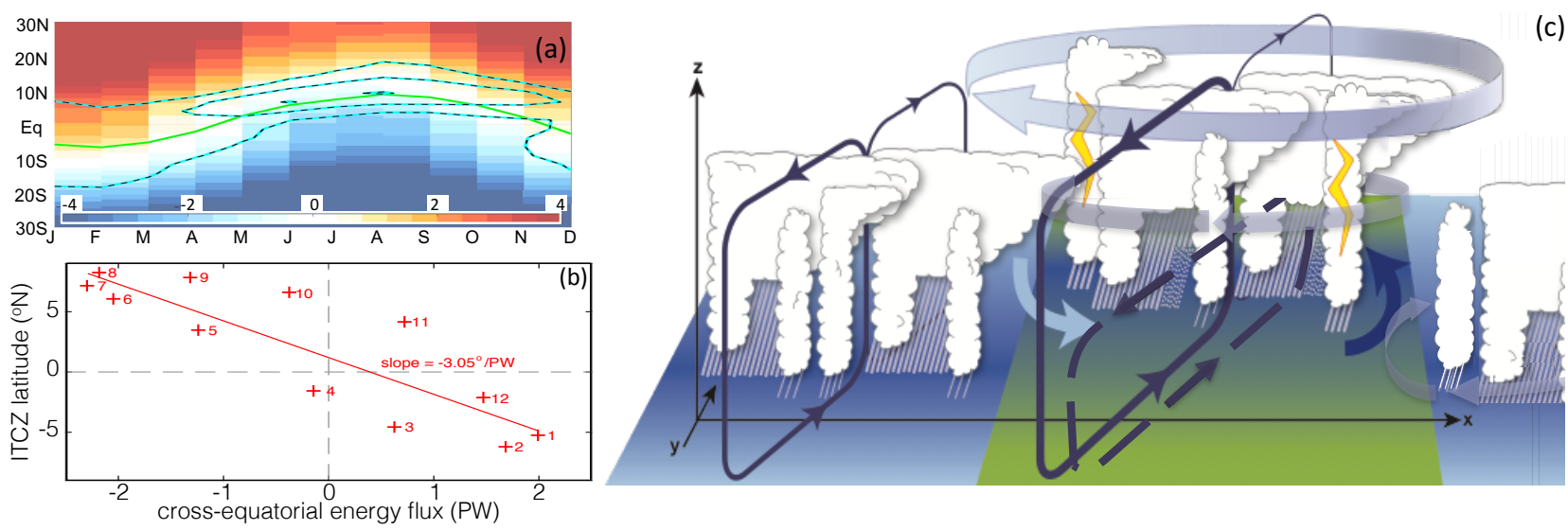

Figure 3: (a) Zonal-mean rainfall (dashed), ITCZ position (green), and zonally- and vertically-integrated atmospheric energy transport (in PW, shaded). (b) Climatological ITCZ latitude as a function of the vertically-integrated atmospheric energy transport at the equator. Numbers correspond to calendar month. The ellipse is sloped at $3^{\circ}$ ITCZ shift per 1 PW energy flux. (c) ITCZ (blue background) and monsoon (green background) schematics. The Hadley cells (dark solid lines) meet in the northern tropics, maximum ascent and rainfall occur in the winter cell (equatorward of the cell boundary) close to maximum low-level MSE (darker surface shading). Monsoons are distinguished by the additional shallow meridional circulation (dashed) and ventilation by the rotational horizontal flows (ribbon arrows) and by a different distribution of cloud types. See on-line methods. 

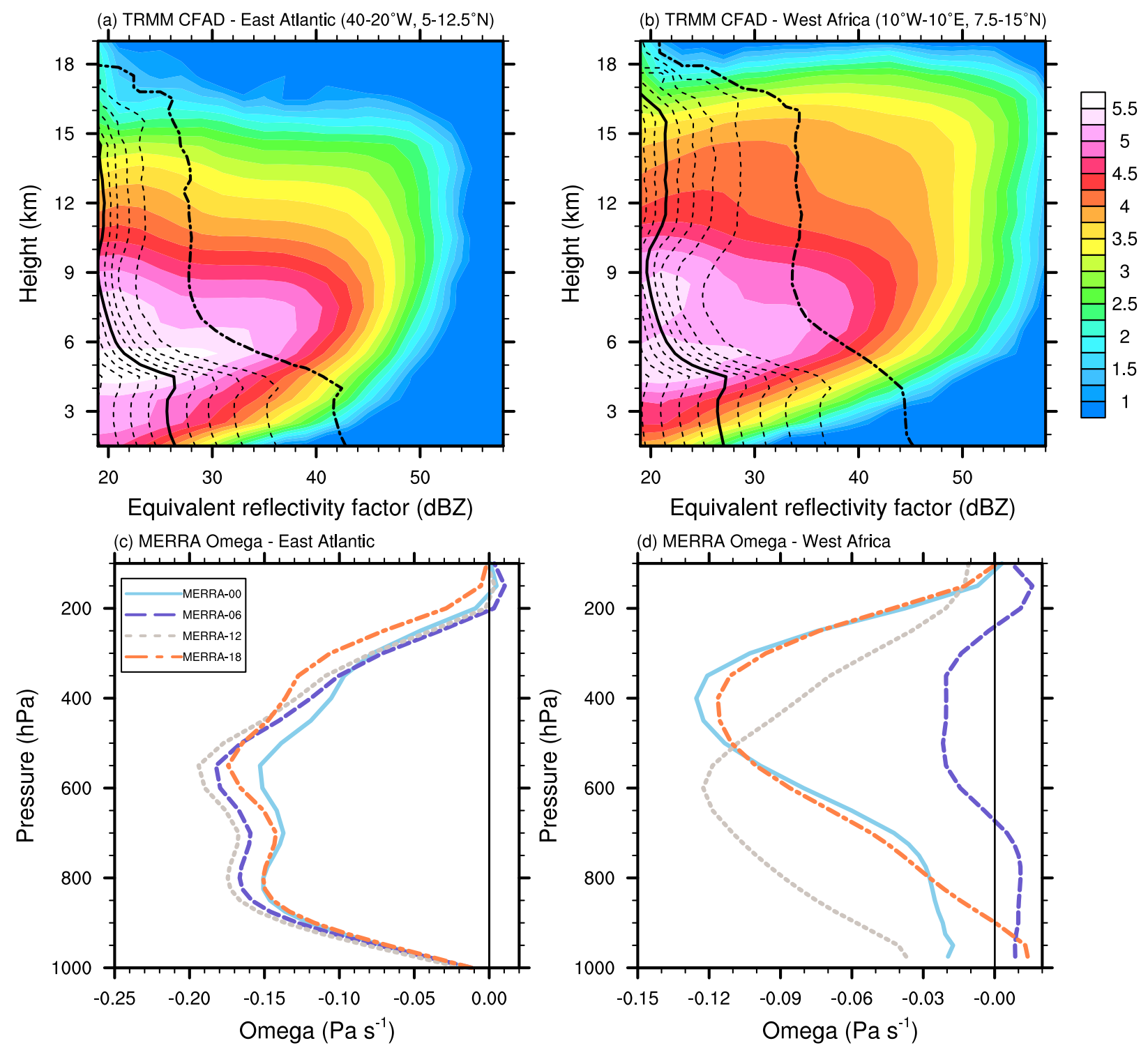

Figure 4: Cloud characteristics (top) and ascent profiles (bottom) over the eastern Atlantic ITCZ (left) and western Africa (right) as function of height. (a-b) The Contoured Frequency with Altitude Diagrams (CFAD, filled contour) shows the frequency (logarithmic scale) of storm-top height as a function of rainfall intensity (units of reflectivity, dBZ). Contours: percentile lines (solid=median, dashed-dotted $=99$ th percentile) of reflectivity frequency. Frequency is normalized at each level and all rain types are included. (c-d) Daily evolution of the vertical velocity profiles (pressure coordinates; negative values indicate upward motion) from 6-hourly MERRA reanalysis. See on-line method section for details. 
1. Braconnot, P. et al. Evaluation of climate models using palaeoclimatic data. Nature Climate Change 2, 417-424 (2012).

2. Harrison, S. P. et al. Evaluation of CMIP5 palaeo-simulations to improve climate projections. Nature Climate Change 5, 735-743 (2015).

3. Harrison, S. P. et al. Mid-Holocene climates of the Americas: a dynamical response to changed seasonality. Climate Dynamics 20, 663-688 (2003).

4. Metcalfe, S. E., Barron, J. A. \& Davies, S. J. The Holocene history of the North American Monsoon: 'known knowns' and 'known unknowns' in understanding its spatial and temporal complexity. Quaternary Science Reviews 120, 1-27 (2015).

5. Chen, F., Yu, Z., Yang, M., Ito, E. \& Wang, S. Holocene moisture evolution in arid central Asia and its out-of-phase relationship with Asian monsoon history. Quaternary Science Reviews 27, 351-364 (2008).

6. Li, Y., Wang, N., Zhou, X., Zhang, C. \& Wang, Y. Synchronous or asynchronous Holocene Indian and East Asian summer monsoon evolution: a synthesis on Holocene Asian summer monsoon simulations, records and modern monsoon indices. Global and planetary Change 116, 30-40 (2014).

7. Hoelzmann, P., Jolly, D. \& Harrison, S. P. Mid-Holocene land-surface conditions in northern Africa and the Arabian Peninsula: A data set for the analysis of biogeophysical feedbacks in the climate system. Global Biogeochemical Cycles 12, 35-51 (1998).

8. Kuper, R. \& Kröpelin, S. Climate-Controlled Holocene Occupation in the Sahara: Motor of Africa's Evolution. Science 313, 803-807 (2006). 
9. Perez-Sanz, A., Li, G., González-Sampériz, P. \& Harrison, S. P. Evaluation of modern and mid-Holocene seasonal precipitation of the Mediterranean and northern Africa in the CMIP5 simulations. Climate of the Past 10, 551-568 (2014).

10. Timm, O., Köhler, P., Timmermann, A. \& Menviel, L. Mechanisms for the Onset of the African Humid Period and Sahara Greening 14.5-11 ka BP*. Journal of Climate 23, 26122633 (2010).

11. Kutzbach, J., Bonan, G. B., Foley, J. \& Harrison, S. P. Vegetation and soil feedbacks on the response of the African monsoon to orbital forcing in the early to middle Holocene. Nature 384, 623-626 (1996).

12. Pausata, F. S. R., Messori, G. \& Zhang, Q. Impacts of dust reduction on the northward expansion of the African monsoon during the Green Sahara period. Earth and Planetary Science Letters 434, 298-307 (2016).

13. Boos, W. R. \& Korty, R. L. Regional energy budget control of the intertropical convergence zone and application to mid-Holocene rainfall. Nature Geoscience 9, 892-897 (2016).

14. Singarayer, J. S. \& Burrough, S. L. Interhemispheric dynamics of the African rainbelt during the late Quaternary. Quaternary Science Reviews 124, 48-67 (2015).

15. Prado, L. F., Wainer, I., Chiessi, C. M., Ledru, M. P. \& Turcq, B. A mid-Holocene climate reconstruction for eastern South America. Climate of the Past 9, 2117-2133 (2013).

16. Steinke, S. et al. Mid- to Late-Holocene Australian-Indonesian summer monsoon variability. Quaternary Science Reviews 93, 142-154 (2014).

17. Tanaka, H. L., Ishizaki, N. \& Nohara, D. Intercomparison of the intensities and trends of Hadley, Walker and monsoon circulations in the global warming projections. Scientific online letters on the atmosphere 1, 077-080 (2005). 
18. Biasutti, M. Forced Sahel rainfall trends in the CMIP5 archive. Journal of Geophysical Research 118, 1613-1623 (2013).

19. Seth, A. et al. CMIP5 Projected Changes in the Annual Cycle of Precipitation in Monsoon Regions. Journal of Climate 26, 7328-7351 (2013).

20. Schneider, T., Bischoff, T. \& Haug, G. H. Migrations and dynamics of the intertropical convergence zone. Nature 513, 45-53 (2014).

21. Emanuel, K., Neelin, J. \& Bretherton, C. S. On large-scale circulations in convecting atmospheres. Q. J. R. Meteorol. Soc. 120, 1111-1143 (1994).

22. Nie, J., Boos, W. R. \& Kuang, Z. Observational Evaluation of a Convective QuasiEquilibrium View of Monsoons. Journal of Climate 23, 4416-4428 (2010).

23. Webster, P., Magana, V. O. \& Palmer, T. N. Monsoons: Processes, predictability, and the prospects for prediction. Journal of Geophysical Research-Oceans 103, 14451-14510 (1998).

24. Donohoe, A., Marshall, J., Ferreira, D. \& Mcgee, D. The Relationship between ITCZ Location and Cross-Equatorial Atmospheric Heat Transport: From the Seasonal Cycle to the Last Glacial Maximum. Journal of Climate 26, 3597-3618 (2013).

25. Wang, B. \& Ding, Q. Global monsoon: Dominant mode of annual variation in the tropics. Dynamics of Atmospheres and Oceans 44, 165-183 (2008).

26. Wang, P. X. et al. The global monsoon across timescales: coherent variability of regional monsoons. Climate of the Past 10, 2007-2052 (2014).

27. Mohtadi, M., Prange, M. \& Steinke, S. Palaeoclimatic insights into forcing and response of monsoon rainfall. Nature 533, 191-199 (2016). 
28. Kang, S. M., Held, I. M., Frierson, D. M. W. \& Zhao, M. The Response of the ITCZ to Extratropical Thermal Forcing: Idealized Slab-Ocean Experiments with a GCM. Journal of Climate 21, 3521-3532 (2008).

29. Chiang, J. C. H. \& Friedman, A. R. Extratropical Cooling, Interhemispheric Thermal Gradients, and Tropical Climate Change. Annual Review of Earth and Planetary Sciences 40, $383-412$ (2012).

30. Held, I. M. \& Hou, A. Y. Nonlinear Axially Symmetric Circulations in a Nearly Inviscid Atmosphere. J. Atmos. Sci. 37, 515-533 (1980).

31. Plumb, R. A. Dynamical constraints on monsoon circulations. In Schneider, T. \& Sobel, A. H. (eds.) The Global Circulation of the Atmosphere, 252-266 (The Global Circulation of the Atmosphere, 2007).

32. Schneider, T. The general circulation of the atmosphere. Annu. Rev. Earth Planet. Sci. 34, 655-688 (2006).

33. Bordoni, S. \& Schneider, T. Monsoons as eddy-mediated regime transitions of the tropical overturning circulation. Nature Geoscience 1, 515-519 (2008).

34. Shaw, T. A. On the Role of Planetary-Scale Waves in the Abrupt Seasonal Transition of the Northern Hemisphere General Circulation. Journal of the Atmospheric Sciences 71, 1724$1746(2014)$.

35. Zhai, J. \& Boos, W. R. Regime Transitions of Cross-Equatorial Hadley Circulations with Zonally Asymmetric Thermal Forcings. J. Atmos. Sci. 72, 3800-3818 (2015).

36. Kang, S. M., Frierson, D. M. W. \& Held, I. M. The Tropical Response to Extratropical Thermal Forcing in an Idealized GCM: The Importance of Radiative Feedbacks and Convective Parameterization. Journal of the Atmospheric Sciences 66, 2812-2827 (2009). 
37. Voigt, A., Bony, S., Dufresne, J.-L. \& Stevens, B. The radiative impact of clouds on the shift of the Intertropical Convergence Zone. Geophysical Research Letters 41, 4308-4315 (2014).

38. Voigt, A. \& Shaw, T. A. Circulation response to warming shaped by radiative changes of clouds and water vapour. Nature Geoscience 8, 102-106 (2015).

39. Frierson, D. M. W. \& Hwang, Y.-T. Extratropical Influence on ITCZ Shifts in Slab Ocean Simulations of Global Warming. Journal of Climate 25, 720-733 (2012).

40. Mcgee, D., Donohoe, A., Marshall, J. \& Ferreira, D. Changes in ITCZ location and crossequatorial heat transport at the Last Glacial Maximum, Heinrich Stadial 1, and the midHolocene. Earth and Planetary Science Letters 390, 69-79 (2014).

41. Frierson, D. M. W. et al. Contribution of ocean overturning circulation to tropical rainfall peak in the Northern Hemisphere. Nature Geoscience 6, 940-944 (2013).

42. Swann, A. L. S., Fung, I. Y., Liu, Y. \& Chiang, J. C. H. Remote Vegetation Feedbacks and the Mid-Holocene Green Sahara. Journal of Climate 27, 4857-4870 (2014).

43. Hwang, Y.-T., Frierson, D. M. W. \& Kang, S. M. Anthropogenic sulfate aerosol and the southward shift of tropical precipitation in the late 20th century. Geophysical Research Letters 40, 2845-2850 (2013).

44. Hwang, Y.-T., Xie, S.-P., Deser, C. \& Kang, S. M. Connecting tropical climate change with Southern Ocean heat uptake. Geophysical Research Letters 44, 9449-9457 (2017).

45. Shaw, T. A., Voigt, A., Kang, S. M. \& Seo, J. Response of the intertropical convergence zone to zonally asymmetric subtropical surface forcings. Geophysical Research Letters $\mathbf{4 2}$, 9961-9969 (2015). 
46. Kay, J. E. et al. Global Climate Impacts of Fixing the Southern Ocean Shortwave Radiation Bias in the Community Earth System Model (CESM). Journal of Climate 29, 4617-4636 (2016).

47. Hawcroft, M. et al. Southern Ocean albedo, inter-hemispheric energy transports and the double ITCZ: global impacts of biases in a coupled model. Climate Dynamics 48, 22792295 (2016).

48. Roberts, W. H. G., Valdes, P. J. \& Singarayer, J. S. Can energy fluxes be used to interpret glacial/interglacial precipitation changes in the tropics? Geophysical Research Letters 44, 6373-6382 (2017).

49. Held, I. M. The Partitioning of the Poleward Energy Transport between the Tropical Ocean and Atmosphere. J. Atmos. Sci. 58, 943-948 (2001).

50. Marshall, J., Donohoe, A., Ferreira, D. \& McGee, D. The ocean's role in setting the mean position of the Inter-Tropical Convergence Zone. Climate Dynamics 42, 1967-1979 (2014).

51. Fedorov, A. V., Burls, N. J., Lawrence, K. T. \& Peterson, L. C. Tightly linked zonal and meridional sea surface temperature gradients over the past five million years. Nature Geoscience 8, ngeo2577-980 (2015).

52. Held, I. M. \& Soden, B. J. Robust responses of the hydrological cycle to global warming. Journal of Climate 19, 5686-5699 (2006).

53. Neelin, J., Munnich, M., Su, H., Meyerson, J. E. \& Holloway, C. E. Tropical drying trends in global warming models and observations. Proc. Natl. Acad. Sci. 103, 6110-6115 (2006).

54. Byrne, M. P. \& Schneider, T. Narrowing of the ITCZ in a warming climate: Physical mechanisms. Geophysical Research Letters 43, 11,350-11,357 (2016). 
55. Lintner, B. R. \& Neelin, J. A prototype for convective margin shifts. Geophysical Research Letters 34, L05812 (2007).

56. Singarayer, J. S., Valdes, P. J. \& Roberts, W. H. G. Ocean dominated expansion and contraction of the late Quaternary tropical rainbelt. Scientific Reports 7, 9382 (2017).

57. Wallace, J. et al. On the structure and evolution of ENSO-related climate variability in the tropical Pacific: Lessons from TOGA. Journal of Geophysical Research: Atmospheres (1984-2012) 103, 14241-14259 (1998).

58. Huang, P., Xie, S.-P., Hu, K., Huang, G. \& Huang, R. Patterns of the seasonal response of tropical rainfall to global warming. Nature Geoscience 6, 357-361 (2013).

59. Chadwick, R., Good, P., Andrews, T. \& Martin, G. Surface warming patterns drive tropical rainfall pattern responses to $\mathrm{CO} 2$ forcing on all timescales. Geophysical Research Letters $\mathbf{4 1}$, 610-615 (2014).

60. Hsu, Y.-H., Chou, C. \& Wei, K.-Y. Land-Ocean Asymmetry of Tropical Precipitation Changes in the Mid-Holocene. Journal of Climate 23, 4133-4151 (2010).

61. Liu, X., Battisti, D. S. \& Donohoe, A. Tropical Precipitation and Cross-Equatorial Ocean Heat Transport during the Mid-Holocene. Journal of Climate 30, 3529-3547 (2017).

62. Back, L. E. \& Bretherton, C. S. Geographic variability in the export of moist static energy and vertical motion profiles in the tropical Pacific. Geophysical Research Letters 33, 392 (2006).

63. Inoue, K. \& Back, L. E. Gross Moist Stability Analysis: Assessment of Satellite-Based Products in the GMS Plane. J. Atmos. Sci. 74, 1819-1837 (2017). 
64. Shaw, T. A. \& Pauluis, O. Tropical and Subtropical Meridional Latent Heat Transports by Disturbances to the Zonal Mean and Their Role in the General Circulation. J. Atmos. Sci. 69, 1872-1889 (2012).

65. Sobel, A. H. \& Neelin, J. The boundary layer contribution to intertropical convergence zones in the quasi-equilibrium tropical circulation model framework. Theoretical and Computational Fluid Dynamics 20, 323-350 (2006).

66. Kelly, P. \& Mapes, B. Asian Monsoon Forcing of Subtropical Easterlies in the Community Atmosphere Model: Summer Climate Implications for the Western Atlantic. Journal of Climate 26, 2741-2755 (2013).

67. Chou, C. \& Neelin, J. D. Mechanisms Limiting the Northward Extent of the Northern Summer Monsoons over North America, Asia, and Africa*. Journal of Climate 16, 406-425 (2003).

68. Adam, O., Bischoff, T. \& Schneider, T. Seasonal and interannual variations of the energy flux equator and ITCZ. Part II: Zonally varying shifts of the ITCZ. Journal of Climate 29, 3219-3230 (2016).

69. Hagos, S. M. \& Zhang, C. Diabatic heating, divergent circulation and moisture transport in the African monsoon system. Quarterly Journal of the Royal Meteorological Society 136, $411-425$ (2009).

70. Hill, S. A., Ming, Y., Held, I. M. \& Zhao, M. A Moist Static Energy Budget-Based Analysis of the Sahel Rainfall Response to Uniform Oceanic Warming. Journal of Climate 30, 56375660 (2017).

71. Taylor, C. M. et al. Frequency of Sahelian storm initiation enhanced over mesoscale soilmoisture patterns. Nature Geoscience 4, 430-433 (2011). 
72. Boos, W. R. \& Kuang, Z. Dominant control of the South Asian monsoon by orographic insulation versus plateau heating. Nature 463, 218-222 (2010).

73. Giannini, A. et al. A unifying view of climate change in the Sahel linking intra-seasonal, interannual and longer time scales. Environmental Research Letters 8, 024010 (2013).

74. Park, J.-Y., Bader, J. \& Matei, D. Northern-hemispheric differential warming is the key to understanding the discrepancies in the projected Sahel rainfall. Nature Communications 6, $5985(2015)$.

75. Liu, Y., Chiang, J. C. H., Chou, C. \& Patricola, C. M. Atmospheric teleconnection mechanisms of extratropical North Atlantic SST influence on Sahel rainfall. Climate Dynamics 43, 2797-2811 (2014).

76. Chiang, J. C. H. et al. Role of seasonal transitions and westerly jets in East Asian paleoclimate. Quaternary Science Reviews 108, 111-129 (2015).

77. Rowell, D. P. The impact of Mediterranean SSts on the Sahelian rainfall season. Journal of Climate 16, 849-862 (2003).

78. Zhai, J. \& Boos, W. R. The drying tendency of shallow meridional circulations in monsoons. Quarterly Journal of the Royal Meteorological Society 143, 2655-2664 (2017).

79. Bretherton, C. S., Peters, M. E. \& Back, L. E. Relationships between Water Vapor Path and Precipitation over the Tropical Oceans. Journal of Climate 17, 1517-1528 (2004).

80. Ahmed, F. \& Schumacher, C. Convective and stratiform components of the precipitationmoisture relationship. Geophysical Research Letters 42, 10,453-10,462 (2015).

81. Bergemann, M. \& Jakob, C. How important is tropospheric humidity for coastal rainfall in the tropics? Geophysical Research Letters 43, 5860-5868 (2016). 
82. Zipser, E., Liu, C., Cecil, D., Nesbitt, S. \& Yorty, D. Where are the most intense thunderstorms on Earth? Bulletin of the American Meteorological Society 87, 1057-1071 (2006).

83. Liu, C. \& Zipser, E. J. "Warm Rain" in the Tropics: Seasonal and Regional Distributions Based on 9 yr of TRMM Data. Journal of Climate 22, 767-779 (2009).

84. Davies, L., Jakob, C., May, P., Kumar, V. V. \& Xie, S. Relationships between the largescale atmosphere and the small-scale convective state for Darwin, Australia. Journal of Geophysical Research-Atmospheres 118, 11,534-11,545 (2013).

85. Dorrestijn, J., Crommelin, D. T., Siebesma, A. P., Jonker, H. J. J. \& Jakob, C. Stochastic Parameterization of Convective Area Fractions with a Multicloud Model Inferred from Observational Data. J. Atmos. Sci. 72, 854-869 (2015).

86. Song, H. et al. Evaluation of Cloud Fraction Simulated by Seven SCMs against the ARM Observations at the SGP Site*. Journal of Climate 27, 6698-6719 (2014).

87. Martin, G. M. et al. Analysis and Reduction of Systematic Errors through a Seamless Approach to Modeling Weather and Climate. Journal of Climate 23, 5933-5957 (2010).

88. Willetts, P. D. et al. Moist convection and its upscale effects in simulations of the Indian monsoon with explicit and parametrized convection. Quarterly Journal of the Royal Meteorological Society 143, 1073-1085 (2017).

89. Marsham, J. H. et al. The role of moist convection in the West African monsoon system: Insights from continental-scale convection-permitting simulations. Geophysical Research Letters 40, 1843-1849 (2013).

90. Daleu, C. L. et al. Intercomparison of methods of coupling between convection and largescale circulation: 1. Comparison over uniform surface conditions. Journal of Advances in Modeling Earth Systems 7, 1576-1601 (2015). 
91. Anber, U., Gentine, P., Wang, S. \& Sobel, A. H. Fog and rain in the Amazon. Proc. Natl. Acad. Sci. 112, 11473-11477 (2015).

92. Cronin, T. W., Emanuel, K. A. \& Molnar, P. Island precipitation enhancement and the diurnal cycle in radiative-convective equilibrium. Quarterly Journal of the Royal Meteorological Society 141, 1017-1034 (2015).

93. Braconnot, P. et al. Impact of different convective cloud schemes on the simulation of the tropical seasonal cycle in a coupled ocean-atmosphere model. Climate Dynamics 29, 501520 (2007).

94. Coats, S. \& Karnauskas, K. Are Simulated and Observed Twentieth Century Tropical Pacific Sea Surface Temperature Trends Significant Relative to Internal Variability? Geophysical Research Letters 44, 9928-9937 (2017).

95. Neelin, J. \& Held, I. M. Modeling tropical convergence based on the moist static energy budget. Mon. Wea. Rev. 115, 3-12 (1987).

96. Raymond, D., Sessions, S., Sobel, A. H. \& Fuchs, Z. The mechanics of gross moist stability. J. Adv. Model. Earth Syst 1, 1-20 (2009).

97. Kageyama, M. et al. PMIP4-CMIP6: the contribution of the Paleoclimate Modelling Intercomparison Project to CMIP6. Geoscientific Model Development Discussions 1-46 (2016).

98. Voigt, A. et al. The tropical rain belts with an annual cycle and a continent model intercomparison project: TRACMIP. J. Adv. Model. Earth Syst 8, 1868-1891 (2016).

99. Eyring, V. et al. Overview of the Coupled Model Intercomparison Project Phase 6 (CMIP6) experimental design and organization. Geoscientific Model Development 9, 1937-1958 (2016). 
100. Zhou, T. et al. GMMIP (v1.0) contribution to CMIP6: Global Monsoons Model Intercomparison Project. Geoscientific Model Development 9, 3589-3604 (2016). 


\section{Methods}

Figure 1: Characteristics of observed tropical rainfall. On any given day, rain is produced by cloud systems that range in size between individual convective towers $(1-10 \mathrm{~km})$ to mesoscale convective systems and tropical cyclones ( $>100$ kilometers). Despite substantial variability on short time scale and small spatial scales, most disturbances are organized within the large-scale rain belts formed by the monsoons and the inter-tropical convergence zone (> $1000 \mathrm{~km})$. The map (a, color) and zonal mean (b, dark green) of daily rainfall are obtained from merged GPM satellite measurements calibrated against rain gauges (Huffman et al., 2015). Column integrated water vapour (a, grey shading and magenta contour) was obtained from the ERA Interim reanalysis product (Dee et al., 2011). The summer climatological zonal mean rainfall (b, light green) is calculated as the 1998-2014 average of the 11-day period centered around July 27th and is obtained from the TRMM-3B42 rainfall estimate (Huffman et al., 2007). Climatological conditional intensity of rainfall (c, color shading, and d) is obtained from the precipitation-radar data on the TRMM satellite (Biasutti et al, 2011) and is expressed as a reflectivity in units of dbZ (decibels of Z). Reflectivity is the amount of transmitted power returned to the radar receiver; light rain is detected by the TRMM PR when the $\mathrm{dBZ}$ value reaches 18 (corresponding to about $0.4 \mathrm{~mm} / \mathrm{hr}$ ). The higher the $\mathrm{dBZ}$, the stronger the rainrate. Uncertainty in the methods for translating reflectivity into a quantitative precipitation estimates are detailed in Villarini and Krajewski (2009). Lightening flashes for July 27th, 2014 are obtained from Lightning Imaging Sensor during ascending passes of the TRMM satellite (https://lightning.nsstc.nasa.gov/lisib/lisbrowse.exe?which=qcyear=2014day=208).

Figure 2: Changes in rainfall in the Holocene indicate a complex behavior across the monsoon systems, not fully captured by climate models, and do not suggest that meridional displacements of the zonal mean ITCZ explain a large fraction of the variance of tropical continental rainfall. (a) The expectation that Southern Hemisphere monsoons would be weaker in periods of 
weaker SH summer insolation is not fully supported by current observations. Quantitative reconstructions of changes in mean annual precipitation (MAP) between the mid Holocene $(11,000-$ 5,000 years before present) and present day in colored circles, the color indicates the size of the anomaly (mm, colorbar) while the size indicates the number of reconstructions used for the estimate, as indicated by the legend inside the map. The data was first published by Bartlein et al (2011). (b) CMIP5/PMIP3 simulated and reconstructed changes in mean annual precipitation in the mid Holocene for $5^{\circ}$ latitude bands across northern Africa (longitude $20^{\circ} \mathrm{W}$ to $40^{\circ} \mathrm{E}$ between 0 and $45^{\circ} \mathrm{N}$ ), where the model results are averages for the grid cells with observations and each model is represented by a different gray circle. The mean and standard error of the reconstructions is shown in black and the number of grid cells contributing to the reconstruction is shown for each latitude band. CMIP5/PMIP3 data were available thanks to the World Climate Research Programme's Working Group on Coupled Modelling, which is responsible for CMIP. For CMIP the U.S. Department of Energy's Program for Climate Model Diagnosis and Intercomparison provides coordinating support and led development of software infrastructure in partnership with the Global Organization for Earth System Science Portals. The figure is modified from Perez-Sanz et al., 2014; (c) Correlation maps (shading) of decadal rainfall variations at each gridpoint with the first principal component of the zonal mean precipitation in the fully-forced TrACE-21000 (OttoBliesner et al, 2014) simulation for the period $9.5 \mathrm{ka}$ to $0.5 \mathrm{ka}$ before present. The dashed line is a representative contour for the mean precipitation and indicates the climatological position of the rain belt.

Figure 3: The energy-budget framework for the tropical rain belt. (a) The seasonal evolution of the zonal mean observed climatological rainfall (dashed contours, only the 4, 6, and $8 \mathrm{~mm} /$ day isolines are shown) and ITCZ position (defined as the centroid of zonal-mean rainfall within $20^{\circ} \mathrm{N} / \mathrm{S}$; green line) are superimposed on a reanalysis-based estimate of the zonally and vertically integrated atmospheric energy transport (shaded, warm and cool colors indicate north- 
ward and southward transport, respectively, and the white area indicates the energy flux equator, units of PW). (b) The seasonal relationship between the vertically integrated atmospheric energy flux at the equator $\left(\mathcal{F}_{o}\right)$ and the ITCZ position. The energy flux associated with the net mass movement between the hemisphere is retained here, leading to a phase lag between the two fields. The slope of the relationship, given by the direction of the major axis of the ellipse, indicates a $3^{\circ}$ shift for a $1 \mathrm{PW}$ energy flux, consistent with calculations that omit the barotropic circulation.

The climatological rainfall in Figure 3a,b is calculated as the 1979-2013 average of the Climate Prediction Center (CPC) Merged Analysis of Precipitation (CMAP) dataset (Adler et al., 2003). The energy fields are from ERA Interim reanalysis (Dee et al., 2011) over the same period. The cross-equatorial energy transport is calculated eliminating the mass budget residual before vertically integrating the fluxes, the data was provided by the National Center for Atmospheric Research (retrieved from https://climatedataguide.ucar.edu/climate-data/era-interimderived-components).

(c) Schematic of the ITCZ (depicted over an oceanic surface, blue half on the left) and monsoon (depicted over a continental surface, green half on the right) circulations for northernhemisphere summer. The summer and winter Hadley cells (dark solid lines) meet in the northern tropics, close to where the low-level moist static energy (MSE) is maximum (darker shading at the surface), consistent with convective quasi-equilibrium theory. Most upward motion and thus most rainfall occurs in the ascending branch of the stronger, winter cell, so maximum rainfall is slightly equatorward of the Hadley cell boundary and the energy-flux equator. As is the case for the ITCZ, rainfall associated with the monsoonal circulation is positioned slightly equatorward of the maximum surface moist energy (dark blue shading) and is associated with large-scale ascent in local meridional overturning cells whose strength is greater when the ascent is further away from the equator. Key distinctions for the monsoons are in the complexity of the circulation and the 
distribution of cloud types. Notice in the land portion of the diagram the presence of a shallow meridional circulation (dashed lines) with ascent poleward of the rain band and a dry return flow, the rotational circulations associated with the low-level cyclone (light and dark blue ribbon-width arrows indicate negative and positive transport of MSE), mid- and upper-level land anticyclones, and the oceanic anticyclone (anticyclonic circulations are depicted with ribbon-width grey arrows). Notice also the deeper and more intense convection over land (indicated by a distribution of clouds that include more overshoots and fewer clouds lacking an anvil), more lightning, less rain from warm cloud (fewer clouds without anvil), and more re-evaporation of rain (dotted rain from the anvil cloud).

This schematic highlights those aspects of an hypothetical "essential" monsoons that are addressed in this paper. It is not meant to represent any particular monsoon system, as each is highly affected by the geometry of the continent, the location and orientation of orography, the geographical distribution of surface types, including deserts, and oceanic processes unique to each ocean basin.

Figure 4: Cloud characteristics and ascent profiles over ocean and land during the peak of the rainy season. Left: the eastern Atlantic ITCZ $\left(40-20^{\circ} \mathrm{W} 5-12.5^{\circ} \mathrm{N}\right)$. Right, western Africa $\left(10^{\circ} \mathrm{W}-10^{\circ} \mathrm{E} 7.5-15^{\circ} \mathrm{N}\right)$. The Contoured Frequency with Altitude Diagrams (CFAD) in the top panels show that western Africa has deeper, more intense convective cells while the eastern Atlantic has more mid-level rainy cloud. The filled contour shows the log of the frequency of storm top height as a function of radar reflectivity (a measure of rainfall intensity). Both regions show that storms reaching $5 \mathrm{~km}$ in height and measuring reflectivities of less than $30 \mathrm{dBZ}$ are the most frequent, but this peak is more pronounced over ocean than land. Conversely, the land region shows more frequent instances of storms that have intensity above 50dBZ (colors extending to the right of the diagram) and reach $18 \mathrm{~km}$ in height (colors extending to the top of the diagram). Overlaid 
on the color are percentile lines of reflectivity frequency at each level with the black line equal to the median at each level. The far right line is the 99th percentile line. Notice that the median surface reflectivity is slightly higher over land, while the 99th percentile reflectivity is much higher over land, indicating that land convection reaches more extreme values of intensity. The secondary reflectivity maximum in the median line is also more noticeable over land than ocean, suggesting again significant differences in the vertical profile of the cloud systems over land and ocean. Frequency is normalized at each level and all rain types (stratiform, convective, shallow isolated, shallow non-isolated) are included. The bottom panels show how ascent profiles in rain systems have much larger diurnal variations over western Africa and are much more top-heavy than over the adjacent ocean. Profiles of vertical velocity in pressure coordinates (negative values indicate upward motion) were obtained from the MERRA reanalysis.

The TRMM reflectivity data (Kummerow et al, 1998) was originally sourced from TRMM orbital files (2A23/2A25) for the 1998-2014 period (August values only). Vertical omega profiles are calculated from 6-hourly MERRA reanalyis (Rieckner et al, 2011) for August days in 19832007. Only samples that contributed the top $50 \%$ of rainfall by volume were included (using the MERRA surface precipitation flux data for all rain and rainfall thresholds unique to each domain and 6-hourly period). When all times are included, the eastern Atlantic ascent is even more bottom heavy than shown in Figure 4, but the qualitative comparison to land convection is unchanged.

\section{Methods References}

101. G. Huffman, D. Bolvin, D. Braithwaite, K. Hsu, R. Joyce, P. Xie. Integrated MultisatellitE Retrievals for GPM (IMERG), version 4.4. NASA's Precipitation Processing Center, accessed 21 December, 2015, ftp://arthurhou.pps.eosdis.nasa.gov/gpmdata/ (2014)

102. Dee, D. P., Uppala, S. M., Simmons, A. J., Berrisford, P., Poli, P., Kobayashi, S., 
et al. The ERA-Interim reanalysis: configuration and performance of the data assimilation system. Quarterly Journal of the Royal Meteorological Society, 137(656), 553-597. http://doi.org/10.1002/qj.828 (2011)

103. Huffman, G.J., R.F. Adler, D.T. Bolvin, G. Gu, E.J. Nelkin, K.P. Bowman, Y. Hong, E.F. Stocker, D.B. Wolff. The TRMM Multi-satellite Precipitation Analysis: Quasi-global, multiyear, combined-sensor precipitation estimates at fine scale. Journal of Hydrometeorology, 8(1), 38-55. (2007)

104. Biasutti, M., Yuter, S. E., Burleyson, C. D., and, A. H. Sobel. Very high resolution rainfall patterns measured by TRMM precipitation radar: seasonal and diurnal cycles. Climate Dynamics, 39(1-2), 239-258. http://doi.org/10.1007/s00382-011-1146-6 (2011)

105. Villarini, G., Krajewski, W. F. . Review of the Different Sources of Uncertainty in Single Polarization Radar-Based Estimates of Rainfall. Surveys in Geophysics, 31(1), 107129. http://doi.org/10.1007/s10712-009-9079-x (2009)

106. Bartlein, P. J., Harrison, S. P., Brewer, S., Connor, S., Davis, B. A. S., Gajewski, K., et al. Pollen-based continental climate reconstructions at 6 and $21 \mathrm{ka}$ : a global synthesis. Climate Dynamics, 37(3-4), 775-802. http://doi.org/10.1007/s00382-010-0904-1 (2011).

107. Perez-Sanz, A., Li, G., Gonzlez-Sampriz, P., Harrison, S. P. Evaluation of modern and mid-Holocene seasonal precipitation of the Mediterranean and northern Africa in the CMIP5 simulations. Climate of the Past, 10(2), 551?568. http://doi.org/10.5194/cp-10-5512014 (2014).

108. Otto-Bliesner, B. L., Russell, J. M., Clark, P. U., Liu, Z., Overpeck, J. T., Konecky, B., et al. Coherent changes of southeastern equatorial and northern African rainfall during the last deglaciation. Science, 346(6214), 1223-1227. http://doi.org/10.1126/science.1259531 (2014). 
109. Adler, R. F., Huffman, G. J., Chang, A., Ferraro, R., Xie, P.-P., Janowiak, J. E., et al. The Version-2 Global Precipitation Climatology Project (GPCP) monthly precipitation analysis (1979-Present). Journal of Hydrometeorology, 4, 1147-1167. (2003).

110. Kummerow, C., Barnes, W., Kozu, T., Shiue, J., Simpson, J. The Tropical Rainfall Measuring Mission (TRMM) Sensor Package. Journal of Atmospheric and Oceanic Technology, 15, 809-817. (1998).

111. Rienecker, M. M., Suarez, M. J., Gelaro, R., Todling, R., Bacmeister, J., Liu, E., et al. MERRA: NASA's Modern-Era Retrospective Analysis for Research and Applications. Journal of Climate, 24(14), 3624-3648. http://doi.org/10.1175/JCLI-D-11-00015.1 (2011). 